\title{
零非正則制御系のシンセシスについて*
}

$$
\text { 伊 藤 正 美** }
$$

\section{Synthesis of Zero Non-regular Control System}

\section{Masami Ito and Hiroaki Kimata}

In this paper the authors have revealed the relations between the transient and steady-state characteristics of the zero non-regular control systems with a zero in the right-half root plane, and the pole-zero configurations of the closed-loop transfer functions in the root plane, and considered on the determination of the closed-loop transfer functions satisfying some specifications. The summarized conclusions are as follows.

1. If the location of the zero in the right-half plane is nearer to the origin than those of the poles in the left-half plane, the indicial response of the system exhibits the large undershoot and the large overshoot.

2. Because of the existence of the undershoot the minimum value of the integral of squared error (ISE) of the system is obtained for non-oscillatory one.

3. The presence of the zero located near the origin on the real axis in the left-half plane, which makes both the undershoot and the overshoot larger, renders the rise time shorter and reduces the steady-state velocity error. Thus the system designer is forced to choose the pole-zero configuration by a compromise between the steady state velocity error and the undershoot (or the overshoot to design type-I servomechanism.

\section{1. 緒言}

系の開回路伝達関数が， $\mathrm{S}$ 平面の右半平面上に零点 をもつ制御系 (零非正則制御系 ${ }^{(1)}$ ) が通常の線 形系 (最小位相推移系) に比し不安定になりやすいことは, 単純ロートトロール形増幅発電機 ${ }^{(2)}$, 発電所水路 ${ }^{(3)}$,

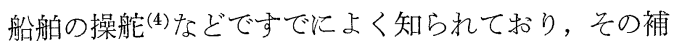
償法についても, 中和補償 ${ }^{(2)}$, フィードバック補償 ${ }^{(5)}$ など(6), 種々論じられている.しかし, これらの補償 法は, 系の安定性に注目することが主眼で, 制御の質 を論ずることは, あまりなされていない。普通, 零非 正則制御系の過渡応答は, 右半平面上の零点により, 逆応答現象を呈することがあるため, 良好な制御性能 を与えるパラメータの值も通常の線形系とは異なるも のと考光られる. それゆえ, 零非正則制御系のシンセ シスに当たっては, 系の過渡応答特性（オーバシュー ト, アンダシュート, 立ら上がり時間など）や定常特 性と制御パラメータ（ $\mathrm{S}$ 平面上の極・零点配置）との 間の関係をはっきりとはあくしておく必要がある。

本稿は, $\mathrm{S}$ 平面の右半面上に 1 個の零点をもつ零非

* 昭和 40 年 1 月 5 日原稿受付

** 名古屋大学工学部
正則制御系について，インディシャル応答扣よび自乗 愦差面積 (ISE) から系の過渡特性の検討を行な い(7) (9), さらに定常特性の検討を加えて, 適当な仕 様条件を満足する閉回路伝達関数のパラメータの範囲, すなわわ， $\mathrm{S}$ 平面上の極零点配置について考察したも のである.

本稿で考察した閉回路伝達関数は, つぎに示す $3 つ$ の場合である。

$$
\begin{gathered}
F_{1}(s)=K_{1} \frac{-(s-a)}{s^{2}+2 \zeta \omega s+\omega^{2}} \\
F_{2}(s)=K_{2} \frac{-(s-a)}{(s+b)\left(s^{2}+2 \zeta \omega s+\omega^{2}\right)} \\
F_{3}(s)=K_{3} \frac{-(s-a)(s+c)}{(s+b)\left(s^{2}+2 \zeta \omega s+\omega^{2}\right)}
\end{gathered}
$$

\section{2. 過 渡 特 性}

本章では，過渡特性を考察することが主目的である から， $K_{1}=\omega^{2} / a ， K_{2}=b \omega^{2} / a, K_{3}=b \omega^{2} / a c$ とし, 定常 位置偏差を 0 として検討を進める。

\section{$2 \cdot 1$ インディシャル応答による考察}

インディシャル応答は, $f(t)=\mathcal{L}^{-1}[F(s) / s]$ として 求められ，Fig. 1 に示すよらな逆応答波形が得られる. Fig. 1 に示すと拈り, アンダシュート, オーバシュー 


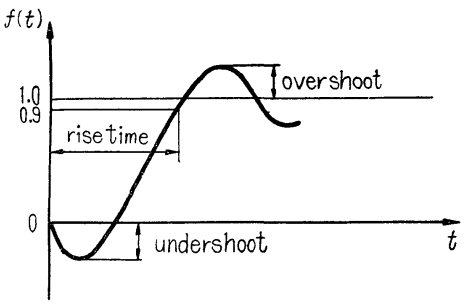

Fig. 1 Definition of overshoot, rise time, and undershoot

，立ち上がり時間を定義する。

$2 \cdot 1 \cdot 1$ 閉回路伝達関数が (1) 式で与えられる場合 の過渡特性 Fig. 2 は，(1)式で $\omega=1$ に規準化し $K_{1}=1 / a$ とした場合のインディシャル応答 $f_{1}(t)=\mathcal{L}^{-1}$ $\left[F_{1}(s) / s\right]$ から求めたアンダシュート,オーバシュート, 立ち上がり時間の各定数 $(\zeta, a)$ に対する值を四示し たものである.一般に, 右半面上の零点の位置が原点 に近いときは，アンダシュート，オーバシュート，立 ち上がり時間はいずれも大きくなり，制御性能が悪く なることがわかる.これは, 左半面上の極と右半面上 の零点との原点に対する相対的位置によってきまるこ とを示して扣り，逆のいい方をして右半面上の零点の 位置汶して, 左半面上の極が原点より遠くなると， アンダシュート，オーバシュートが大きくなるという こともできる.

この関係をもっと直観的に示すために，(1)式で, $a=1\left(K_{1}=\omega^{2}\right)$ とした場合のインディシャル応答を求 め, 1例として, オーバシュート $(O)$, アンダシュー ト $(U)$, 立ち上がり時間 $(R)$ に対して

$$
O \leqq 0.3, \quad U \leqq 0.4, R \leqq 4
$$

の仕様条件を与えたとき，これを満足する $\omega ， \zeta$ の範 囲を求めてみよう. Fig. 3 は $\omega-\zeta$ 平面上, Fig. 4 は $\mathrm{S}$ 平面上での合格領域を示したものである.通常の線 形系と比較して著しく異なることは, アンダシュート

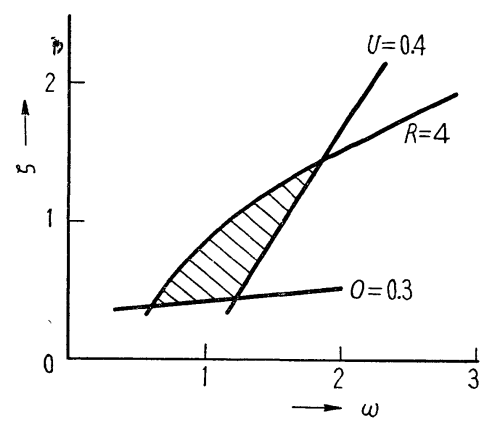

Fig. 3 Region satisfying Eq (4) in $\omega-\zeta$ plane [case of $\mathrm{Eq}(1)$ ]

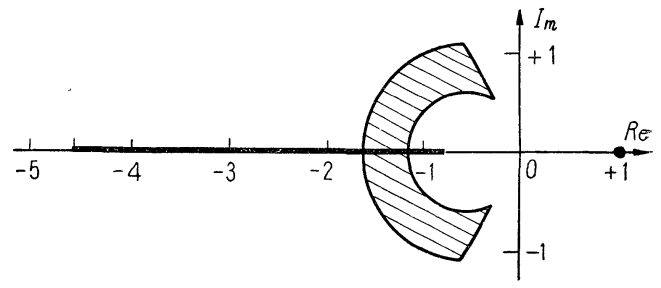

Fig. 4' Region satisfying Eq. (4) in root-plane [case of Eq. (1)]

に対する制限条件のために固有周波数 $\omega$ の上限が存在 することである.な拉，普通の線形系でも，ノイズ除 去のために $\omega$ に上限をもたせ低域ろ波特性にするが， これは上の（アンダシュートによる）制限条件とは本 質的に違うものである。そして，いを大きくとること によって, 右半面上の零点に対する左半面上の極の原 点からの相対的位置が遠くなることにより，アンダシ ュートが大きくなることを示しているものにほかなら ない。

$2 \cdot 1 \cdot 2$ 閉回路伝達関数が (2) 式で与えられる場合 の過渡特性この場合は, (1) 式の場合にさらに左 半面上飞実極 1 個をそら入した場合に相当するもので， 実極のそら入が過渡特性にどのよらに影響するかを検
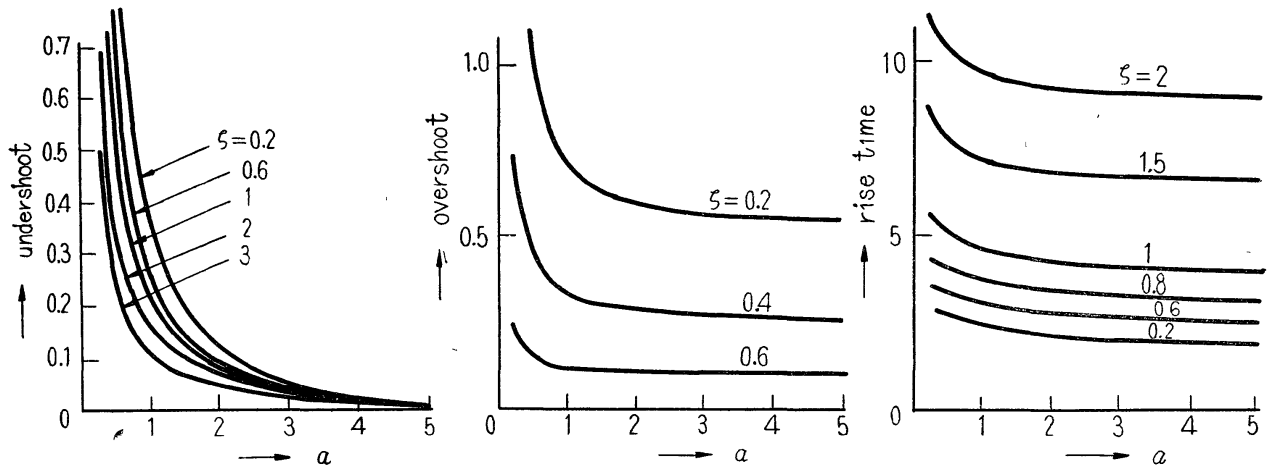

Fig. 2 Undershoot, overshoot, and rise time in case of Eq. (1) 

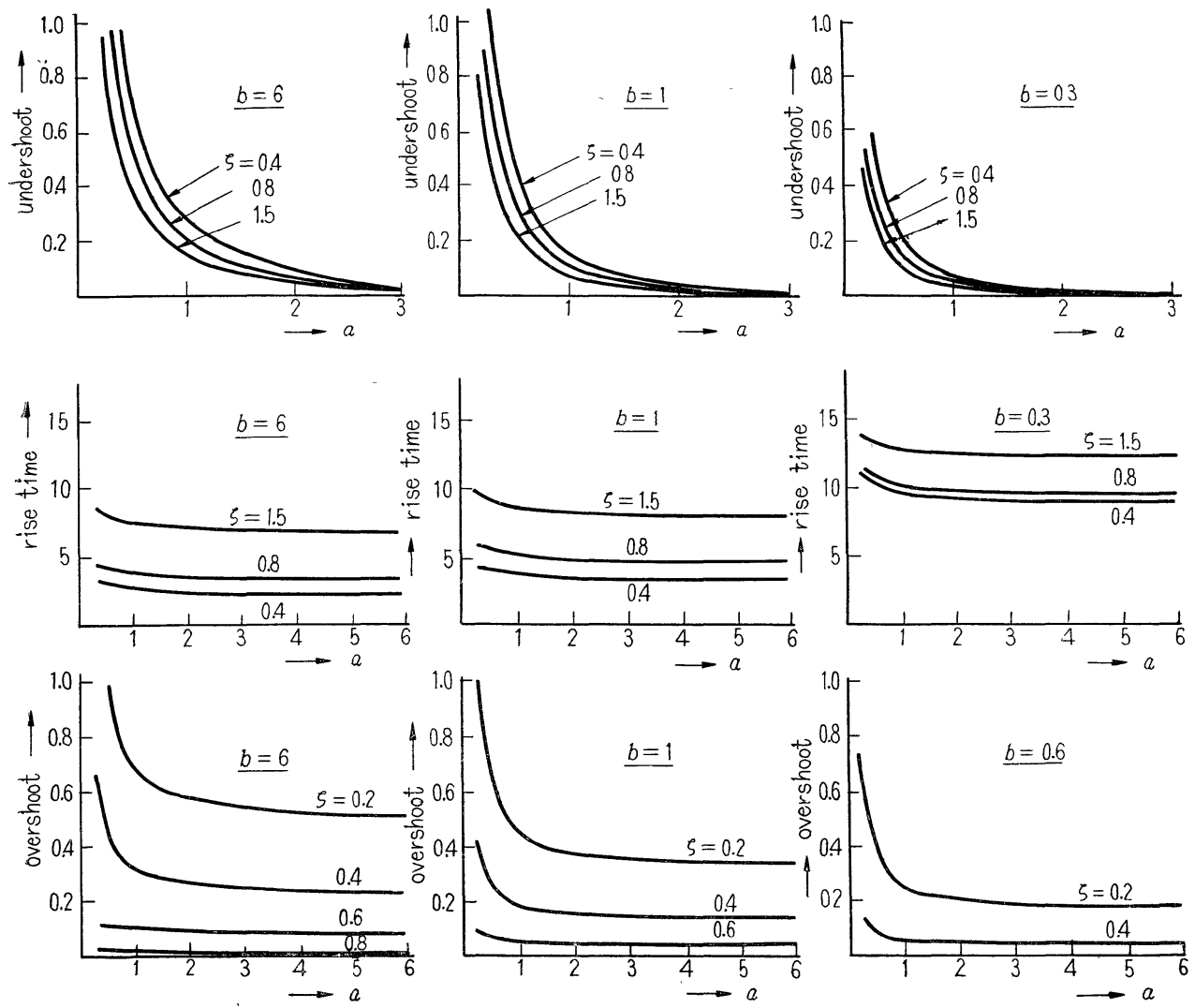

Fig. 5 Undershoot, rise time, and overshoot in case of Eq. (2)

\section{討しよう。}

Fig. 5 は (2)式で $\omega=1$ 飞規準化し， $K_{2}=b / a$ とお いた場合のインディシャル応答 $f_{2}(t)=\mathcal{L}^{-1}\left[F_{2}(s) / s\right]$ から求めたアンダシュート,オーバシュート, 立ち上 がり時間の各定数 $(\zeta, a, b)$ に対する值を図示したも のである. 原点の近くに右半面上の零点をるつ（ $a$ の 小さい) 系がアンダシュート, オーバシュート, 立ち 上がり時間ともに大きく制御しにくいことは，(1)式 の場合と同様であるが，適当な左半面実極のそう入 (小さなb)によってアンダシュート，オーバシュー トを軽減できることがわかる，この場合，立ち上がり が遅くなるのはやむを得ない。

前項 $(2 \cdot 1 \cdot 1)$ の場合々同様, (2) 式て $a=1\left(K_{2}=\right.$ $\left.\omega^{2} b\right)$ とした場合のインディンャル応答を求め, (4) 式の仕様条件を与光たときのこれを渾足する $\omega ， \zeta$ の 範团を求めると, Fig. 6 亿示すように得られる。 Fig. 3 と比較すれば左半面実極の存在による $\omega-\zeta$ 合格領 域の変化の様子がわかる. 立ち上がり時間の犠牲が合 格領域をらの小なるほうへ移動させ，アンダシュート， オーバシュートの軽減が合格領域を広げている.
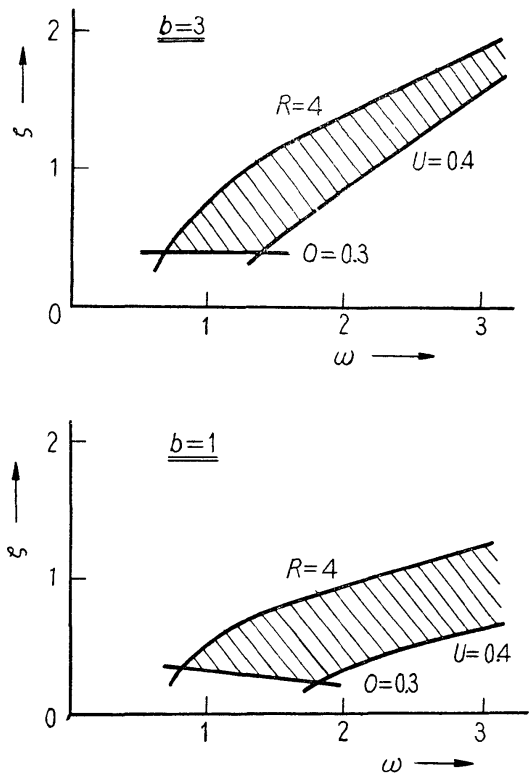

Fig. 6 Region satisfying Eq. (4) in $\omega-\zeta$ plane [case of Eq. (2)] 
$2 \cdot 1 \cdot 3$ 閉回路伝達関数が (3) 式で 与えられる場合の過渡特性この場 合は，(2)式の場合にさらに左半面実 蟿上に零点 1 個をそう入した場合であ る.Fig. 7 は, (3)式で $\omega=1$ に規準 化し， $K_{2}=b / a c$ と执いた場合のイン ディシャル応答 $f_{3}(t)=\mathcal{L}^{-1}\left[F_{3}(s) / s\right]$ から求めたアンダシュート, オーバシ ュート, 立ち上がり時間の各定数 ( $\zeta$, $a, b, c)$ 飞対する值を $\zeta=0.6$ を例と して図示したるのである. 原点近くの 右半面比零点学毛つ系が制御しにくい ことは, 前の 2 つの場合と同じである. 乙かし, 左半面実軸上に適当な零点 （小さな $c$ ）をそう入することによっ て, 前項 $(2 \cdot 1 \cdot 2)$ の場合で犠牲にし た立ち上がり時間を早くすることがで きる。
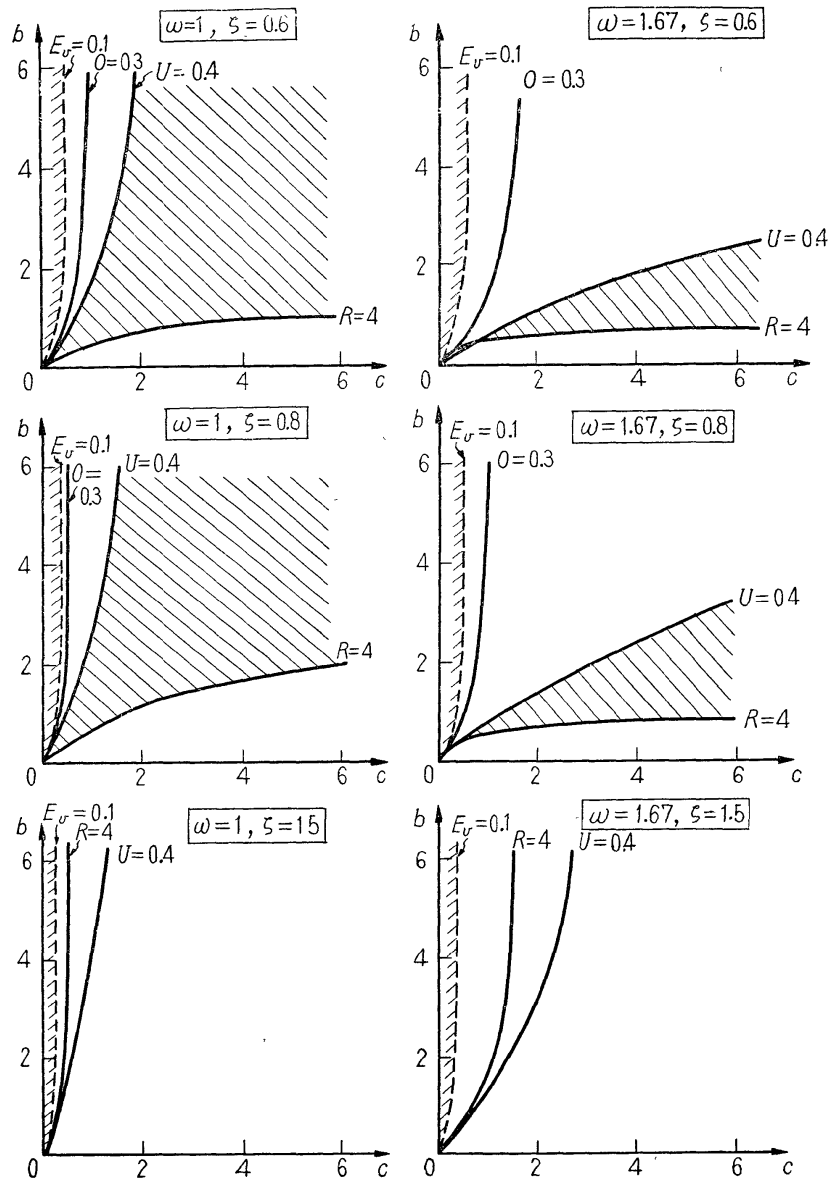
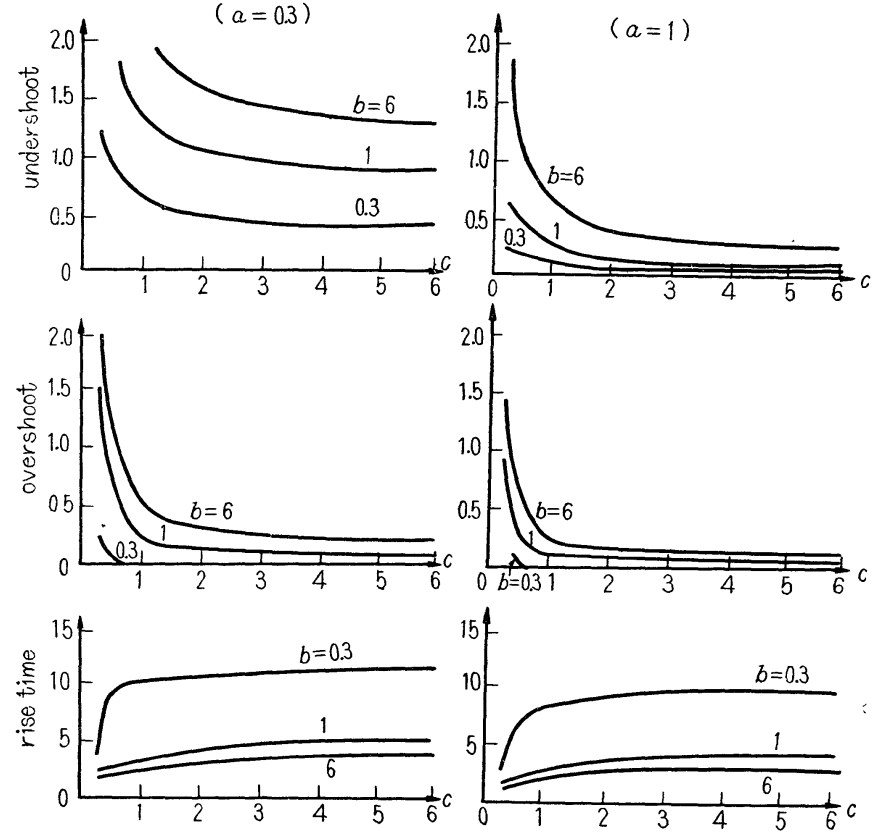

Fig. 7 Undershoot, overshoot, and rise time in case of Eq. (3)

前の 2 つの場合之同様，（3）式で $a=1\left(K_{3}=\omega^{2} b / c\right)$ とした場合のインデ イシャル応答を求め, これから，(4) の仕様条件を䟺足するパラメータの合 格範朋を求めると Fig. 8 に示すよう 㥂られる。（合格領域は斜線で因ま れた部分） $\zeta=1.5$ では $O=0.3$ は， ひごょうに $b$ 軸に近いので描かれてい ない。

Fig. 8 カらもわかるよらに，原点に 近く左半面上の零点をとう入すること は，立ち上がり時間を早めることはで きるが，アンダシュート，オーバシュ 一ト（特にアンダシュート）が大きく なる. 左半面上の実極とのか权合いで， 左半面上の零点を決定することが望ま しい,そして, この零点は, 次節て述 べる定常速度偏差之密接な関係をもつ ため, 特に重要である。

Fig. 8 Region satisfying Eq. (4) in $b-c$ plane [case of Eq. (3)] 

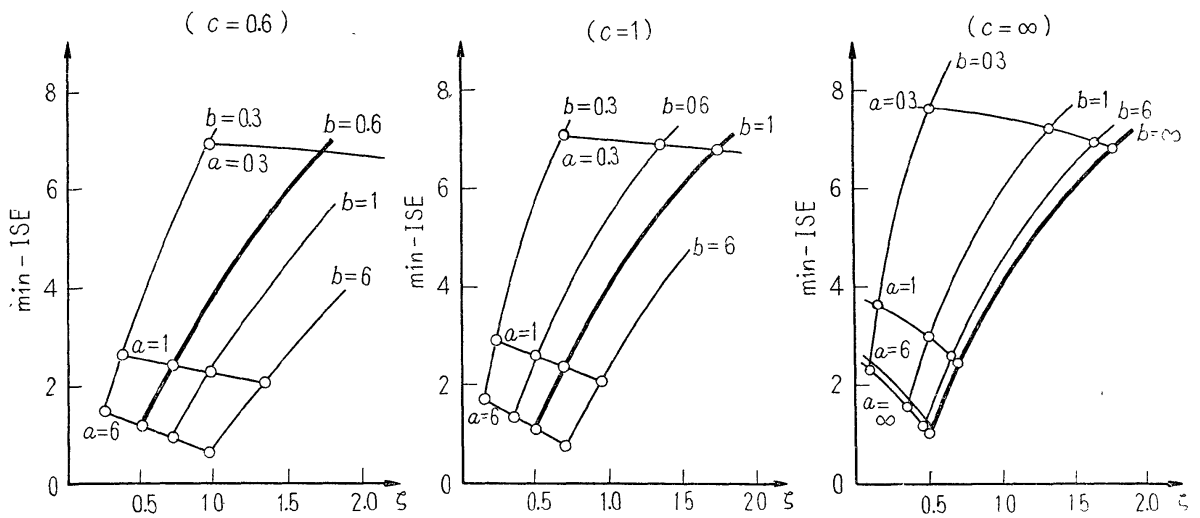

Fig.9 Minımum of integral of squared error (ISE)

\section{$2 \cdot 2$ 自乗誤差面積 (ISE) による考察}

(1) (2)（3）式で $\omega=1$ に規準化し，それぞれ $K_{1}$ $=1 / a, K_{2}=b / a, K_{3}=b / a c$ とした場合の自乗䛊差面積 $(\mathrm{ISE})=\int_{0}^{\infty}\{1-f(t)\}^{2} d t$ を求め, その最小值とそれ を最小にするらの值を各定数 $(\dot{a}, b, c)$ に対して求めた のが Fig.9 である.ここで，太線(各図共通)は（1） 式の場合で, 最右の図が(2)式の場合である.一般に 通常の線形系（最右の図の $a=\infty$ ) ではらの小さい, かなり振動的な系で ISE 最小值をもつが(10), 零非正 則制御系では， $a$ が小さくなると（右半面上の零点が 原点に近くなると）最小点はのの大きい(非振動根の) ほらへ移動することがわかる。これは，アンダシュー トの存在による影響とみられる。そして，小さな $b$ の 存在（左半面上の実極の存在）は, アンダシュート, オーバシュートを軽減し，立ち上がりを犠牲にするた

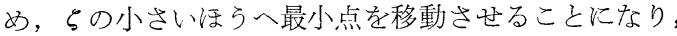
左半面原点近くの実零点のそう入（小さな $c$ ）は，立 ち上がり時間を早めアンダシュート，オーバシュート を大きくするため, 非振動根をもつ（らの大きい）と ころで ISE 最小値をもつことになる。

㭠して，零非正則制御系では，アンダシュートの存 在のため，通常の線形系に比し，かなり非振動的な系 が ISE 最小の判別条件を満足することがわかる。 そ れゆえ，設計のさいに ISE 判別を利用するときは， この点をはっきりと認識する必要がある。

\section{3. 系のシンセシス}

まず，定常位置偏差が問題となるO形の系の閉回路 位達関数の極零点配置について考它ら。この場合は, (1) （3) 式の閉回路伝達関数で， $K_{1}, K_{2}, K_{3}$ をとれ ぞれ $\omega^{2} / a, b \omega^{2} / a, b \omega^{2} / a c$ に近い值に選ぶことができ れば，定常位置偏差を0に近い值とすることができる.
またすでに過渡特性については検討ずみで，たとえば， (4)式のような仕様条件を満足するパラメータの組み 合わせは Fig. 3, Fig. 4, Fig.6 和よび Fig.8 のよ らに与えられる。これらから望ましい極零点配置の決 定が可能である。

つぎに，定常速度偏差が問題となる1形の系の閉回 路伝達関数の極零点配置について考它よう。普通 1 形 の系では，定常位置偏差は０と执くこができるから， 閉回路伝達関数の一般式は

$$
F(s)=\frac{p_{1} p_{2} \cdots \cdots p_{n}}{z_{1} z_{2} \cdots \cdots z_{m}} \cdot \frac{\left(s+z_{1}\right)\left(s+z_{2}\right) \cdots\left(s+z_{m}\right)}{\left(s+p_{1}\right)\left(s+p_{2}\right) \cdots\left(s+p_{n}\right)}
$$

とかかれ，その定常速度偏差は，

$$
E_{v}=\sum_{j=1}^{n} \frac{1}{p_{j}}-\sum_{j=1}^{m} \frac{1}{z_{j}}
$$

となる(11)。それゆえ，(1)〜（3）式の場合の定常速 度偏差は,

$$
\begin{aligned}
\left(K_{1}=\omega^{2} / a,\right. & \left.K_{2}=b \omega^{2} / a, K_{3}=b \omega^{2} / a c \quad \text { とする }\right) \\
E_{v 1} & =\frac{2 \zeta}{\omega}+\frac{1}{a} \\
E_{v 2} & =\frac{2 \zeta}{\omega}+\frac{1}{a}+\frac{1}{b} \\
E_{v 3} & =\frac{2 \zeta}{\omega}+\frac{1}{a}+\frac{1}{b}-\frac{1}{c}
\end{aligned}
$$

である。上式からすぐにわかるように定常速度偏差を 軽減するには, 左半面実軸上の零点 $(c)$ を原点に近 くそう入することである。それゆえ（1)式拉よ゙（2） 式の形の閉回路伝達関数をもつ系では, たと党ば $a=1$ の位置に在半面上の零点をもつ場 合には， $E_{v 1}>1$, $E_{v_{2}}>1$ の定常速度偏差をもつことになり，1 形サー ボ機構としてあまり満足すべきものといえない。

さてそれでは, 左半面上に零点をもつ場合について 検討してみよう。いま， $a=1$ の位置に右半面上の零 

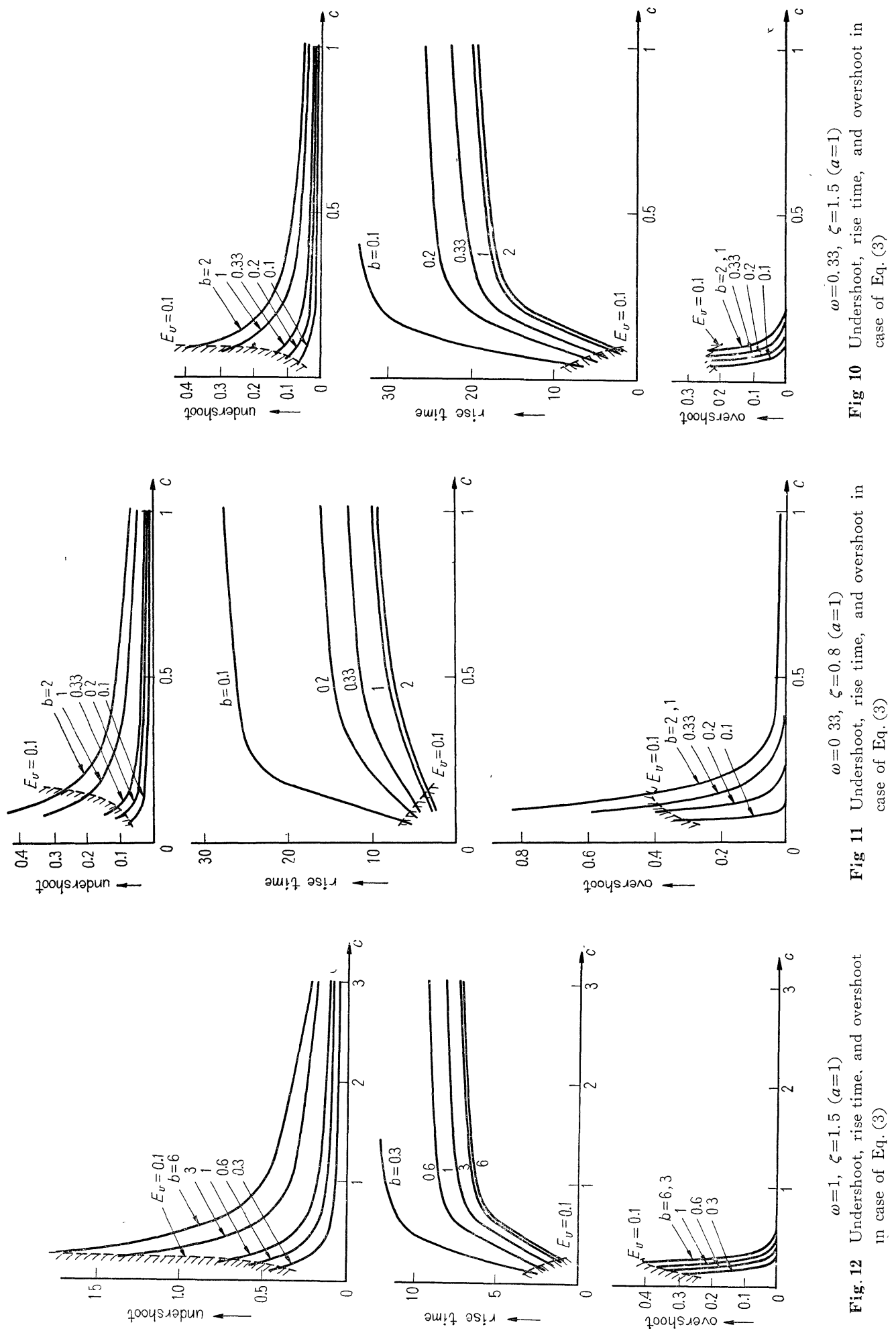

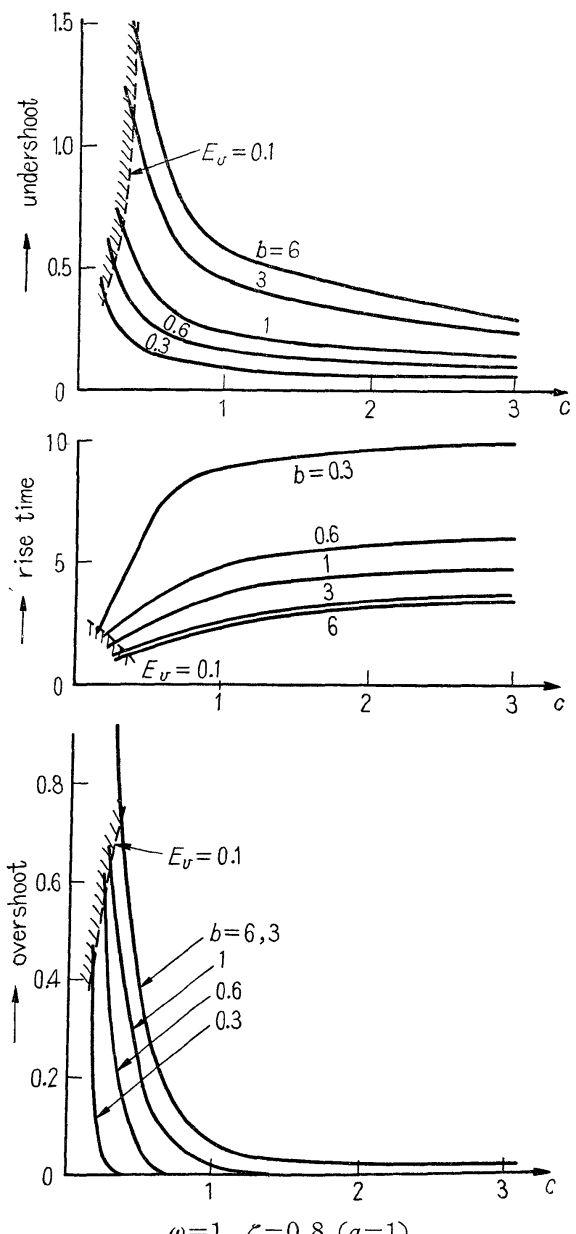

Fig. 13 Undershoot, rise time, and overshoot in case of Eq. (3)

点をもつ場合を考光, 過渡特性に対する仕様条件は (4)式で与兄れるとすると，すでに，前節で検討し たように Fig. 8 亿示すような合格パラメータ領域を 得る. そこで， $E_{v} \leqq 0.1$ を満足する領域を Fig. 8 上 に図示すると，点線から左の部分として得られる。す なわち，cの大きな範囲では，(4)式の仕様条件の合 格領域にはいってこない，この原因は，アンダシュー ト，オーバシュート（特にアンダシュート）に対する 制限条件によるもので，吅っきょく，右半面上の零 点によって起こるものである. そ机ゆ光, 左半面上の 極の右半面上の零点に対する原点からの相対的位置を 小さくしてやって, 右半面上の零点の影響を軽減して やれば，アンダシュートを少なくできることが考光ら れる。

すなわち，この事情は，Fig.10，Fig.11，Fig.12，

Fig.13 によってはっきりする. Fig. 10〜13 は $a=1$
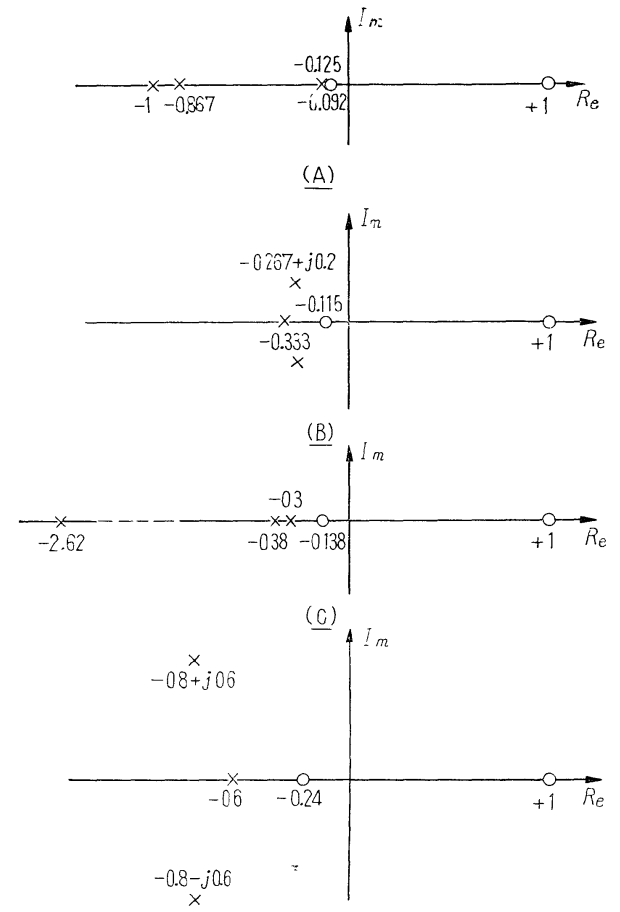

(D)

Fig. 14 Pole-zero configurations

の位置に右半面上の零点をもつ場合の $\omega=1,0.33$ お よび $\zeta=1.5,0.8$ 亿対するアンダシュート，オーバ シュート, 立ち上がり時間と $b, c$ との関係を示し たものである. 図中, $E_{v}=0.1$ は定常速度偏差 $\left(E_{v}\right)$ が 0.1 の值を示すときで，影の部分は， $E_{v} \leqq 0.1$ であ

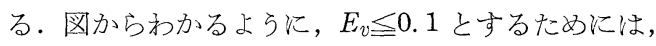
$c$ を小さく選ばねばならず， $c$ を小さくすると，立ち 上がり時間 $(R)$ は短くなるが，アンダシュート $(U)$, オーバシュート $(O)$ が大きくなる. 1例として Fig. 14 の上らな極零点配置を考学ると，つぎに示す， $U$, $R, O, E_{v}$ の值をるつ.
(A) $a=1, \quad \omega=0.33, \quad \zeta=1.5, \quad b=1, \quad c=0.092$, $U=0.27, R=3.27, O=0.22, \quad E_{v}=0.1$
(B) $a=1, \omega=0.33, \zeta=0.8, b=0.333, c=0.115$, $U=0.11, R=4.83, O=0.40, \quad E_{v}=0.1$
(C) $a=1, \quad \omega=1, \quad \zeta=1.5, \quad b=0.3, \quad c=0.138$, $U=0.36, R=2.88, \quad O=0.28, \quad E_{v}=0.1$
(D) $\quad a=1, \quad \omega=1, \quad \zeta=0.8, \quad b=0.6, \quad c=0.24$, $U=0.53, R=2.02, O=0.57, E_{v}=0.1$

けっきょく, 定常速度偏差とアンダシュート（ある いはオーバシュート）との間に適当な妥協が必要で, アンダシュートを軽減するため，過渡特性を支配する 左半面上の極の右半面上の零点汶対する相対的位置を 
原点の近くに之り，定常速度偏差軽減のため, 左半面 上原点に近く零点をとら入するような極零点配置が望 ましい。

\section{4. 結言}

以上得られた結論を要約すると，つぎのと和りであ る.

（1）右半平面上の零点の左半平面上の極に対する 相対的位置が，原点に近いとき，アンダシュー ト，オーバシュートが大きくなり，制御しにく く,アンダシュートの存在は固有周波数 $\omega$ に上 限を生ぜしめる。

（2）左半面実軸上に新た㥛をそら入するとアン ダシュート，オーバシュートを軽減できる。

(3) 左半面実軸上の零点のそう入は，アンダシュ 一ト，オーバシュートは大きくなるが，立ち上 がり時間を早くすることができ，定常速度偏差 を軽減する。

（4）零非正則制御系では, アンダシュートの存在 のため，比較的非振動的な系で，自乗誤差面積 最小値をもつ.
（5）定常速度偏差を問題とする1 形のサーボ機構 では定常速度偏差とアンダシュート（あるいは オーバシュート）との間で適当な妥協を行なっ た極零点配置を選ぶ必要がある。

終わりに，計算・資料作成などにご協力いただいた 本学・近藤正季君，西川富夫君に深謝の意を表する.

\section{参 考 文 献}

（1）乘松, 伊藤: 電学誌, Vol. 81, p. 566 (1961)

(2) 乗松・茂木：電学誌, Vol. 77, p. 149 (1957)

(3) A. Garde : Automatic and Manual Control(Edited by A. Tustin) p. 503 (1952)

(4) H.Chestnut \& R.W. Mayer: Servomechanisms and Regulating System Design, Vol.1, p. 187 192 (1951)

（5）森・松本: 生産研究，10，No.2， p. 409 (1958)

（6）山口・伊沢 : 自動制御，Vol.2， p. 277 (1963)

（7）伊藤：計測自動制御学会第3 回学術講演会, No. 403 (1964)

（8）伊藤：第 7 回自動制御連合講演会, No.147 (1964)

（9）伊藤・木全 : 昭和 40 年電学連大 (1965年 4 月)

（10）山口・藤井・小川：第 2 回自動制御連合講演会前刷, 106 (1959)

(11) J.G. Truxal : Control System Synthesis, p. 282 (1955) -Book-
( 106 ページからづつく)

\section{5. 結言}

相関々数の測定法として簡単な乱数電圧法の一般化 として, 乱数電圧の振幅密度分布が方形分布と異なる 任意の分布に対する相関々数測定の公式を求めた。こ れにより乱数電圧の密度分布が方形分布からずれた場 合の測定誤差の評価ができる。また，方形密度分布を もつ乱数電压の発生方法を考案した. 最後に相関々数 を乱数電圧法に上り測定する場合，考慮しなければな らない誤差を解析・評価した。これにより测定条件が 明らかになった。
終わりに有益な助言をいただいた池辺潤先生に深く 感謝いたします。

$$
\text { 参考文 献 }
$$

(1) J. Ikeda, T. Sato : A New Integrator Using Random Voltage, Electrical Journal of Japan, 6, 1964.

（2）佐藤拓宋：乱数電厌法による相関器に関する 2,3 の 考察，自動制御，Vol. 3, No. 2, p. 48，2， 1964.

(3) J.C. West : Analytical Techniques for Nonlíner Control Systems, Eng. Univ. Press, p. 169, 1960.

(4) П.А. Кругько : Статистическал динамика импульсных систем, Издатепьство, “Советское радио”, Москва-1963, СТР 353 358.

(5) John W. Brean and others: Notes on Analogue-Digital Conversion Techniques, MIT Press, 1957. 